\title{
Analysis of Suria Characters in Katak Hendak Jadi Lembu Based on Cardinal Virtues
}

\author{
Fitri Nur Fadilah ${ }^{1}$, Dewaki Kramadibrata ${ }^{2}$ \\ ${ }^{1}$ Indonesian Studies Program, Faculty of Humanity, Universitas Indonesia, Indonesia \\ ${ }^{2}$ Literature Department, Faculty of Humanity, Universitas Indonesia, Indonesia
}

dewaki56@gmail.com

\begin{abstract}
This article examines the novel Katak Hendak Jadi Lembu by Nur Sutan Iskandar. Nur Sutan Iskandar is known as a prolific author from Balai Pustaka. The study focuses on portraying of Suria characters by using Platon's thinking about the success of human life leading to happiness. Discussion is carried out using the method of library analysis. Based on the analysis of the text and its relation to Platon's thinking, it appears that the figure of Surya does not have four virtues in his life. His life ended in vain.
\end{abstract}

Keyword: Suria, Characters, Cardinal Virtues.

\section{INTRODUCTION}

Nur Sutan Iskandar is known as one of the prolific authors from Balai Pustaka. He was born on November 3, 1893 in Sungaibatang, Maninjau, West Sumatra. During the Independence Revolution, he became a member of the Central Indonesian National Committee (KNIP). In his retirement, he became a lecturer at the Faculty of Literature, Universitas Indonesia. For his services in the field of culture, on May 20, 1961 the Government of Indonesia gave Nur Sutan Iskandar an award "Satya Lencana Kebudayaan"[1]. He died in Jakarta on November 28, 1975 at the age of 82 years.

Nur Sutan Iskandar's work, which was published by Balai Pustaka, are Salah Pilih (1928), Apa Dayaku karena Aku Perempuan (1922), Tjinta jang Membawa Maut (together with Abd. Ager, 1926), Karena Mertua (1932), dan Hulubalang Raja (1934). His novels which contain responses to human life phenomena are Tuba Dibalas dengan Susu (1933), Katak Hendak Jadi Lembu (1935), Neraka Dunia (1937), Dewi Rimba (1935), and Cinta dan Kewajiban (1941).

Balai Pustaka which was established on September 22, 1917 is known as the publisher in Indonesia [2]. As a government printing company, Balai Pustaka implements three main functions: (1) publishes older classical literary works and folktales in regional languages, (2) translates Western literature into Indonesian, and (3) publishes modern Indonesian literature[3]. At that time, Balai Pustaka stipulated that each work was not just a reading, but could provide an information and education.

Katak Hendak Jadi Lembu written in 1935, a period known as the "misses" era or the age of malaise [4].At that time, there was an economic chaos in Europe which had an impact on the the Netherland-Indies. Many people lived in suffer in that era. 
Nur Sutan Iskandar used the malaise era as a story setting to describe Suria's behavior as a child who was not well educated. Suria, the only child of Hajj Zakaria, is very spoiled by his father. In a troubled era, Suria did not care about the difficulties of life at that time. He lives like a rich man, arrogant, does not respect his wife, children, and people around him. When his wife died, Suria realized that his life was not right.

\section{METHOD}

This paper discusses the behavior of Syria in the perspective of three parts of the soul, namely epithumia (appetite), thumos (passion), and nous (intellect), delivered by Platon. The three parts of the soul can be referred to as three movements of the soul because the three parts of the soul have the potential to move or change (kineton) to reach their areté (achieving optimal function). In the context of humans, humans achieve their areté if every part of the human soul reaches its primacy in life. There are four virtues of human life, namely temperance, courage, wisdom, and justice. Discussion is carried out using the method of library analysis.

\section{DISCUSSION}

\subsection{Three Parts of the Soul}

In the history of Ancient Greek thought, Platon was one of the philosophers who produced a thought about politics. This thought is found in one of his works entitled Politea or The Republic. The Republic consists of ten books that contain the ideal democracy according to Platon. The Republic contains ideas about ideal leaders, synergies that should be formed in society, and ideal (city) policies.

The description of the division of the soul is extracted from Aretè: Hidup Sukses Menurut Platon [5]. The division of the three powers of the soul in The Republic (Politeia) is explained in chapter IV entitled Phaidros. According to the myth in Phaidros, the human soul is described as having the task of "following the goddess horse procession". The goddess's horse-drawn carriages are drawn by two pairs of perfect horses and go up to the sky as the highest beauty. The human horse-drawn carriage has a lot of difficulty going up to the back of the sky because the human soul is pulled by two pairs of conflicting horses. The white horses are able to obey the coachman, while the black horses tend to be disobedient and always want to move down so that they cannot go up. This myth describes the soul as a movement that moves from itself [5].

In connection with myths about the soul, Platon in Phaidros illustrates that the human soul consists of three parts, namely epithumia, thumos, and logistikon (the logical, from logos). Epithumia (the black horse) is a part of the human soul that represents low passions such as lust for money and sex. When people are only centered on fulfilling property and money, it will be referred to as philokrematon. Low lust in epithumia will be very difficult to stop gratification and even destroy human beings themselves [5]. If this low lust (epithumia) is successfully controlled, a virtue of temperance will emerge (sophrosune, moderation).

Platon reviews this moderation in his book Xarmides[6]. There are six definitions relating to moderation, namely calmness, shame, doing one's own business, doing good actions, knowing oneself, and universal science. However, in Indonesian, it can be interpreted as "introspective" behavior. One needs to control his low passions so that the person can be introspective. People who are introspective will always be aware of their own desires and passions. 
Thumos (the white horse) is located above the epithumia, which is in the thorax, between the neck and chest diaphragm. Even though the location is around the chest, this part does not refer to the lung or heart organs. This element refers to the form of "effectiveness, enthusiasm, and aggressiveness". Although it is more easily directed by reason, thumos can be irrational and endanger the integrity of a human being. People who are too in love with their self-esteem, family self-esteem, and their nation can abandon all rational considerations and do things that endanger themselves [5]. If his life is centered on the quest for victory, he will be called the philonikon. Meanwhile, if it is centered on prestige search and respect, it will be called philotimon [5]. If the desires related to effectiveness and aggressiveness can be subdued by the ratio, a virtue of courage will emerge (andreia, courage) [5].

Logistikon (the coachman) is located in the whole head. This part is the most important and the best in the human soul. Logistikon (the rational function of the soul) has the duty to govern and control two other parts of the soul. Because of its position close to thumos, they can work together to control epithumia (the black horse). However, if in a conscious state epithumia still cannot be controlled, the logistikon will send orders and advice through dreams when someone is asleep [5]. If logistikon is well trained to "tame" epithumia and thumos, this ratio will produce a virtue of wisdom (sophia, wisdom) [5].

The separation of soul into three parts is made based on the conflicts experienced by the three parts with each other. Movement of desire in human beings as "the desire to follow, reject, or also anticipate something" at the same time can clash with each other [5]. Epithumia will continue to push people towards material fulfillment, thumos will encourage people to win something, and logistikon will encourage people to seek truth[7]. However, if the movement of desire that continues to contradict can be controlled properly, a harmony in the human soul will be formed. If logistikon, thumos, and epithumia reach the level of their respective virtues, there will be a harmonious justice (dikaiosune, just) [5]

That is what is called Aretè. According to Platon's thought, Aretè is a condition when humans become the best human beings [5]. When each part is integrated and supports each other with each other's virtues, this is what is called the cardinal virtues, namely temperance (sophrosune), courage (andreia), wisdom (sophia), and justice (dikaiosune) [5]

\subsection{Suria Characters Based on Cardinal Virtues}

Katak Hendak Jadi Lembu tells the story of Suria, the only child of wealthy Hajj Zakaria. He is known as a spoiled, dandy, and proud boy. He was betrothed to Zubaidah, Haji Hasbullah's son, preacher in Tasikmalaya. At that time, Suria worked as an assistant clerk at the Tasikmaya Resident's Office. Even so, the cost of his life was borne by his father.

When his father died, Syria received inheritance. He became arrogant and left Zubaidah. At that time, Zubadiah was pregnant with his first child. The birth and education costs of his first child were then borne by Haji Hasbullah.

After the inheritance depleted, Syria returned to Zubaidah. He was appointed as Mantri of Sumedang Regency. He became arrogant for being an amtenar (official government). He felt his degree was high because he thought that he was of the prijaji (aristocrat) lineage. He likes to wear good clothes, likes to go for excursions, watch comedy, and join parties everywhere.

Suria earns a small salary, but he spends a lot of money on his own behalf. He doesn't care that the debt is increasing. This made Zubaidah worried about the future of their three children. As a result, there are often debates between them due to financial problems. However, it does not change the nature of Suria who love to be praised and respected by others. 
After a long time in service, Syria felt entitled to occupy a position as clerk. However, the position fell to Kosim, his men. Suria is angry and hates Kosim.

One time, he realized that his debt was very large. He failed to get a loan from his friends. Suria is desperate so that he dares to use office cash.

Suria decided to quit his job and leave Sumedang. Together with his wife and two children, Suria lives at Abdul Halim's home, his first child, in Bandung. Suria's excessive behavior in interfering with Abdulhalim's household affairs made Zubaidah depressed. She was sick, then died.

After Zubaidah passed away, a dispute broke out between Suria and Abdulhalim. Suria was forced to leave Abdulhalim's house and go to Jakarta. In Jakarta, Syria realized the difficulty of finding a job because of the age of malaise. With feelings of shame, regret, and guilt, Suria returns to his hometown in Rajapolah, then disappears.

According to the three images of Platon's soul, the movements of the soul of Syria revolve between epithumia and thumos. If it is associated with epithumia, his life is controlled by lust for fun. The center of his life focuses on fulfilling property and money. When he acquired inheritance, he became arrogant and had the heart to leave his wife. In this case, Suria seems to have the concept of happiness related to money. Thus, he can be called a philokrematon.

If it is associated with thumos, Suria becomes a power-oriented person. He desires to rise in rank to get more power and his self-esteem increases. He boldly asked to be promoted to the rank of cleric. In this situation, he can be called philotimon.

Unfortunately, this desire is not fulfilled. This desire to rise in rank is based on an envy of Kosim, his men. Envy causes bad influences to him. He became a person who pursued wealth with his epithumia and also pursued the fulfillment of his big name with his thumos. In this case, Suria only pursues material fulfillment.

Thumos also moves the spirit of Suria to carry out acts of courage, but not in a good sense: reckless/desperate. When he had to pay his debt, Suria did not have money and did not get a loan from his friends. Therefore, he was determined to use office cash to pay his debts. He committed corruption. In this case, the movements of the Suria soul return to epithumia.

In terms of logistikon, Suria still has a small ratio, which is when he calculates its debt. However, when he knew the amount of his debt, he was then dragged back to the thumos movement. He misused his power by taking office cash to pay off his debts. The ratio of Suria was seen again when he finally sold his house and property to pay off his debt.

Supposedly, after he can pay off his debt, he can live happier. Apparently, this is not the case. When his life was financed by his child, the movement of his soul returned to epithumia and thumos. He still lives in having fun and remains arrogant. That caused his wife to become sick and eventually die.

The soul movement of Suria is between epithumia and thumos. Logistikon in the soul of Suria is very small because he is controlled by lust in matters of material and honor. Thus, Suria cannot reach Aretè: the ultimate human being who is happy.

Thus, Syria does not have the four virtues of life. He does not have the virtue of temperance because he is bound by wealth and wealth. He was unable to be introspective so he could not control his desires. He does not have the virtue of courage in the right sense. He dared to ask for a promotion because of his arrogancy. He dared to commit corruption to maintain his good name. The value of courage in Syria is negative. Thus, he cannot obtain the virtue of justice because epithumia, thumos, and logistikon cannot work together in him. This unfair attitude was seen when he left his wife, burdened the cost of living his wife and his first child to his father in law, and finally he burdened his first child to support himself and his family. 


\section{CONCLUSION}

As an author in Balai Pustaka, Nur Sutan Iskandar followed the policy set by Balai Pustaka. Katak Hendak Jadi Lembu display the Suria story as a result of wrong educations. As the only child of a wealthy parent, he is accustomed to living in luxury. After his assets are gone, he cannot adjust to the situation. In Indonesian, katak hendak jadi lembu (the frog wants to be an ox) is a proverb that means "poor people who live like rich people". That is a picture of Suria's behavior which is filled with lust.

In the perspective of the three parts of the Platonic soul, human virtue based on ratios is to achieve ultimate happiness. In the novel Katak Hendak Jadi Lembu, it is seen that the movements of the soul of Syria are between epithumia and thumos. He is referred to as the philokrematon because he only focuses on living things and money. In addition, he is also called the philotimon because of his arrogancy. He cannot attain the virtue of wisdom because he cannot balance epithumia and thumos with his ratio.

Suria does not have cardinal virtues. He lives by following his passions and not being introspective. Therefore, he cannot reach Aretè, a happy life. His life ended in vain.

\section{REFERENCES}

[1] P. L. Tobing, Nur Sutan Iskandar Mengetjewakan Lebih Banjak Membela Diri. Sinar Harapan, 1971.

[2] M. Mahayana, "Politik dalam Sastra Zaman Balai Pustaka," www.sastraindonesia.com, 2008. .

[3] M. Ricklefs, Sejarah Indonesia Modern 1200-2008. jakarta: PT Ikrar Mandiriabadi, 2008.

[4] N. S. Iskandar, Katak Hendak Jadi Lembu, 11th ed. Jakarta: Balai Pustaka, 2008.

[5] A. . Wibowo, Aretè: Hidup Sukses Menurut Platon. Yogyakarta: Kanisius, 2010.

[6] A. . Wibowo, Xarmides (Tentang Keugaharian). Yogyakarta: Kanisius, 2015.

[7] G. R. F. Ferrari, "The Three-Part Soul," in The Cambridge Companion to Plato's Republic, G. R. F. Ferrari, Ed. Cambridge: Cambridge University Press, 2007, pp. 165201. 